\title{
Investigating the Utilisation of Different Variables for Direct Gravity Trip Distribution Model for Air Passenger Demand
}

\author{
Hitapriya Suprayitno \\ Civil Engineering Department \\ Sepuluh November Institute of Technology \\ Surabaya, Indonesia \\ suprayitno.hita@gmail.com
}

\begin{abstract}
Air Passenger Demand Model for prediction is a capital knowledge. Direct Gravity Trip Distribution Model seems the most appropriate for this prediction. Direct Gravity Trip Distribution model was tried to be developed, calculated by using iterative method. The research give indication that the Direct Gravity Trip Distribution can be developed and used. The general formula has been developed. A good combination of variables are still needs to be investigated. The calculation method has been refined by using the Mean Absolute Error as accuracy indicator. The research indicated that using single variables for each attraction mass and the impedance is better. For the research case, combination of population and ticket tariff give the best model. The Direct Gravity Trip Distribution Model is appropriate to be used for the case of point to point transportation service.
\end{abstract}

Keywords: transport model, trip distribution, direct gravity trip distribution, air passenger

\section{INTRODUCTION}

According to the Transport Planning Principle [1] and the Infrastructure and Facility Asset Management Principle $[2,3]$, the Airport Transportation System need to be assessed and planned periodically. This inludes the airport, the airport network, and the commercial flight service. The planning must be based on Prediciton of Passenger Demand. Thus, the ability to make a Prediction of Transport Demand is capital. This research is a continuation research on Direct Gravity Trip Distribution Model (DGTDM) for predicting Air Passeneger Demand [4].

It has been explained in the previous research that the Conventional 4 Steps Model has been researched a lot for all of the steps. Various research on Conventional 4 Steps Gravity Trip Distribution Model has been executed. These discuss stratification of the trip distribusion based on trip purpose, the difference formulation for passenger and freight, the trip length distribution pattern, the various detterence function, the method to define the minimum sample size in getting a good detterence function, etc. It has been shown also that the Conventional 4 Steps Model need a lot of calculation to produce the Trip Distribution [5-11]. It has been shown that the DGTDM calculation is much easier than the Conventional 4 Steps Model [4,12]. Eventhough, the DGTDM is not yet researched deeply and extensively enough.
The previous research found that the DGTDM can be easily developed. The DGTDM used the attraction masses and the impedance elements. The population and the economic masses can be used for attraction masses, and the distances and the tarriffs can be used for the impedance elements. A certain iterative successive calculation method has been used, with a certain measure of minimization parameter and a measure of accuracy. The previous experiment try several composition of four variables, which all were put in once into the model. The composition variation lay on the various different powering mode. The previous best model of that four variations has been found as presented below [4].

$\mathrm{T}_{\mathrm{ij}}=1.0 \mathrm{E}-17 \times\left(\mathrm{P}_{\mathrm{i}} \mathrm{P}_{\mathrm{j}}\right)^{0.930} \times\left(\mathrm{E}_{\mathrm{i}} \mathrm{E}_{\mathrm{j}}\right)^{0.995} \times \mathrm{Dij}^{-0.999} \times \mathrm{Ta}_{\mathrm{ij}}{ }^{-1.000}$

Now, it is necessary to evaluate the utilization of different combination of variables.

This paper present the result of an attempt to evaluate the utilization of different variables for Direct Gravity Trip Distribution Model for Air Passenger Demand. The previous reserach case, Blangkajeren Air Passenger Demand is taken also for this research.

\section{RESEARCH METHOD}

This research is aimed to evaluate the result of utilizing different variables for Direct Gravity Trip Distribution Modeling. This research is a continuation of the previous research, in which the Model Formula has been developed and tested. This research method is practically the same as the previous one, except that the formula development was not yet necessary [4]. On the other hand, the accuracy measure was improved in this research.

\section{RESEARCH ANALYSIS}

\section{A. Blangkajeren Commercial Flight Services}

As a continuation research, this research used the same case as the previous one, the two commercial flights from Blangkajeren to Banda Aceh and to Medan. Blangkajeren is a district in Aceh Province [4]. It has an airport, the Senubung Airport. The flight map is presented in Figure 1 below. 


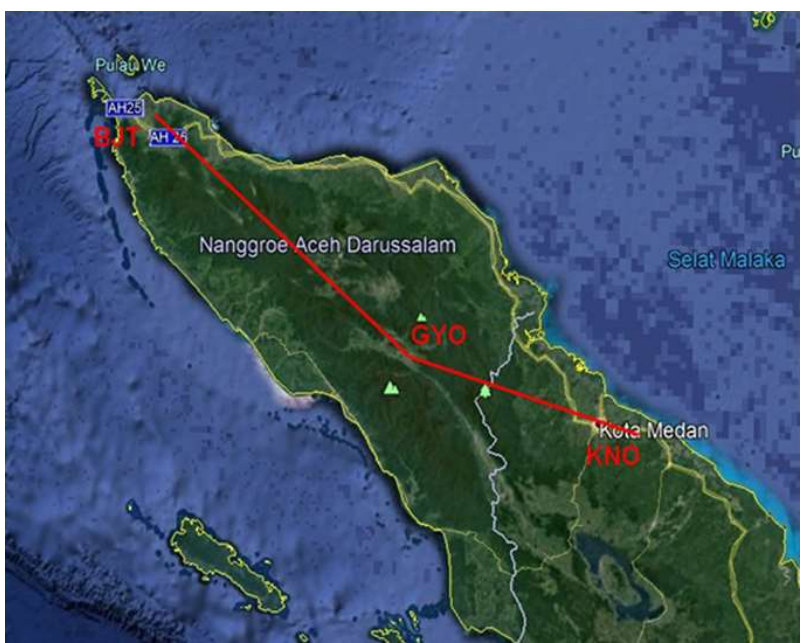

Fig. 1. Flight Map : Blangkajeren - Banda Aceh - Medan.

\section{B. Four Steps Gravity Trip Distribution Model}

The Conventional 4 Steps Trip Distribution Formula can be divided into two big groups: the Gravity Trip Distribution Model and the Growth Factor Model. The Gravity Trip Distribution Model, often called as synthetic model, is presented in (2) below $[1,8]$.

$$
T_{i j}=P_{i} \times A_{j} \times f\left(C_{i j}\right)
$$

Where:

$\mathrm{T}_{\mathrm{ij}} \quad$ : number of trips from zone $\mathrm{i}$ to zone $\mathrm{j}$

$\mathrm{P}_{\mathrm{i}} \quad$ : number of Trip Production in zone $\mathrm{i}$

$\mathrm{A}_{\mathrm{j}} \quad$ : number of Trip Attraction in zone $\mathrm{j}$

$\mathrm{f}\left(\mathrm{C}_{\mathrm{ij}}\right) \quad$ : the deterrence function

which can be formulized in various formula.

The English version use 3 different formula: negative power, negative exponential, and tanner. The American version, call as Friction Function, use various statistical distribution formula.

It can be seen from (2), that the Trip Generation (Trip Production and Trip Attraction) and the Deterrence Function must be calculated first, before the Trip Distribution can be calculated afterward [1].

There are 4 types of overall calculation methods for Conventional Gravity Model, i.e. UCGR (Unconstrained Gravity Model), PCGR (Production Constrained Gravity Model), ACGR (Attraction Constrained Gravity Model, and DCGR (Double Constrained Gravity Model) [1, 8].

\section{Direct Gravity Trip Distribution Model}

Different from the 4 Steps Gravity Trip Distribution Model, the Direct Gravity Trip Distribution Model is developed directly based on data on number of trips, attraction mass and impedance value. That is why this is called Direct Model, since the Model can be gotten directly from a single calculation. The General Formula for Direct
Gravity Model has been developed and tested [4]. The DGTDM general formula can be expressed as (3) below.

$$
T_{i, j} \infty K \times M_{i}^{a} \times M_{j}^{b} \times I_{i, j}^{c}
$$

Where :

$$
\begin{array}{ll}
\mathrm{T}_{\mathrm{ij}} & \text { : number of trip from } \mathrm{i} \text { to } \mathrm{j} \\
\mathrm{K} & \text { : attraction coefficient } \\
\mathrm{M}_{\mathrm{i}} & : \text { mass of } \mathrm{i} \\
\mathrm{I}_{\mathrm{ij}} & : \text { impedance from } \mathrm{i} \text { to } \mathrm{j} \\
\mathrm{K}, \mathrm{a}, \mathrm{b}, \mathrm{c} & \begin{array}{l}
\text { : constants, the impedance variable is negative } \\
\text { powered }
\end{array}
\end{array}
$$

For this research, as the previous one, variables of the above Direct Gravity Trip Distribution are defined as follows : Attraction Masses are defined as Population and Economic Mass (Gross Regional Product - GRP), while the Impedances are defined as Distance and Ticket Tarriff [4]. Therefore (3) is modified into (4) below.

$$
T_{i, j} \infty K \times P_{i}^{a} \times P_{j}^{b} \times E_{i}^{c} \times E_{j}^{d} \times D_{i, j}^{e} \times T \alpha_{i, j}^{f}
$$

Where :

$$
\begin{array}{ll}
\mathrm{T}_{\mathrm{ij}} & : \text { number of passenger trip from } \mathrm{i} \text { to } \mathrm{j} \\
\mathrm{P}_{\mathrm{i}} & : \text { population of } \mathrm{i} \\
\mathrm{E}_{\mathrm{i}} & : \text { economic condition (GRP) of zone } \mathrm{i} \\
\mathrm{D}_{\mathrm{ij}} & : \text { distance between zone } \mathrm{i} \text { to zone } \mathrm{j} \\
\mathrm{Ta}_{\mathrm{ij}} & : \text { ticket tarriff from zone i to zone } \mathrm{j} \\
\mathrm{K}, \mathrm{a}, \mathrm{b}, \mathrm{c}, \mathrm{d}, \mathrm{e}, \mathrm{f} & : \text { constants, the impedance are powered by } \\
& \text { negative value }
\end{array}
$$

\section{Calculatiom Method}

The same calculation method as used in previous research still used here [4]. In order to be mentioned easily, it is better to give a name to this calculation method. In this paper the calculation method is named Successive Iterative Calculation to Minimize Error (SICME). It is about finding the constant values of a nonlinear formula with several variables. The constants can be a multiplication, addition or a powering constant. The constant values are search one by one, successively, by holding the other constant value at a certain fix value. In each iteration a constant value is calculated to minimize the Sum of Square Error (SSE) of the model value to the real value. The accuracy is measured by Mean Absolute Error (MAE). The MAE formula is presented in (5) below.

$$
M A E=\sum_{1}^{n} \frac{\left|e_{i}\right|}{n}
$$

Where:

MAE : mean absolute error 


$$
\begin{array}{ll}
\mathrm{e}_{\mathrm{i}} & : \text { error of model value } \mathrm{i}^{\text {th }} \\
\mathrm{n} & : \text { number of OD points }
\end{array}
$$

\section{E. Research Data}

As a continuation experiment, this research used the same data as the data of the previous one [4]. The data are flight related data and gravity force related data. The data are presented in TABLE I and TABLE II below.

TABLE I. FLIGHT DATA

\begin{tabular}{|l|l|l|l|l|}
\hline No & Flight & $\begin{array}{c}\text { Passenger } \\
\text { pass/month }\end{array}$ & $\begin{array}{c}\text { Distance } \\
k m\end{array}$ & $\begin{array}{c}\text { Tariff } \\
\text { thousand- } \\
\text { rupiah/flight }\end{array}$ \\
\hline 1 & GYO - BJT & 28.75 & 288.47 & 372 \\
\hline 2 & GYO - KNO & 29.50 & 154.61 & 342 \\
\hline
\end{tabular}

TABLE II. ATtRACTION MASSES [13 - 15]

\begin{tabular}{|l|l|l|l|}
\hline No & \multicolumn{1}{|c|}{ Zone } & \multicolumn{1}{|c|}{$\begin{array}{c}\text { Population } \\
\text { person }\end{array}$} & \multicolumn{1}{c|}{$\begin{array}{c}\text { GRP } \\
\text { million rupiah }\end{array}$} \\
\hline 1 & Blangkajeren & 95379 & 2438949 \\
\hline 2 & Banda Aceh & 356983 & 16808137 \\
\hline 3 & Medan & 2210624 & 204299850 \\
\hline
\end{tabular}

\section{F. Evaluation of Utilization of Different Variables}

1) Direct Gravity Trip Distribution Model: As developed and used in the previous research, the Direct Gravity Trip Distribution Model used is presented in the following (6) [4].

$$
T_{i j}=K \times P_{i}^{a} \times P_{j}^{b} \times E_{i}^{c} \times E_{j}^{d} \times D_{i j}^{e} \times T \alpha_{i j}^{f}
$$

Where:

$\begin{array}{ll}\mathrm{T}_{\mathrm{ij}} & : \text { number of air person trip from } \mathrm{i} \text { to } \mathrm{j} \\ \mathrm{P}_{\mathrm{i}} & : \text { population of } \mathrm{i} \\ \mathrm{E}_{\mathrm{i}} & : \text { GRP of } \mathrm{i} \\ \mathrm{D}_{\mathrm{ij}} & : \text { distance betwwen } \mathrm{i} \text { to } \mathrm{j} \\ \mathrm{Ta}_{\mathrm{ij}} & : \text { air ticket tariff from } \mathrm{i} \text { to } \mathrm{j} \\ \mathrm{K}, \mathrm{a}, \mathrm{b}, \mathrm{c}, \mathrm{d}, \mathrm{e}, \mathrm{f} & : \text { constant, the e \& } \mathrm{f} \text { are negative powers }\end{array}$

Notation for the next four models are the same as the above notation, thus the notations are not repeated for the next four formula.

Four different models as variations of the General Model are then developed. Each model were developed by using attraction masses variable an impedance elements. The population and economic mass were used for attraction masses. While distances and ticket tariffs were used for impedance. The four model is then compared to the best of the four previous model. In this case, it is named as Model 0. Calculation and comparaison are presented below.

2) Model 0 : The Best Model from Previous Research: The best Model of the previous experiment used population and economic as attraction mass and distances and tariffs as the impedance elements [4]. The populations and the economics are each grouped together and powered differently. The experiment gave the $\mathrm{P}$ is powered by 0.930 , the economic is powered by 0.995 , while the impedance elements, the distances and the tarriff are each powered by 0.999 and -1.000 respectively. In term of accuracy, this mdoel give errorrs of $99.3 \%$ and $0.5 \%$. The Model is presented in (7) below, while the accuracy calculation result is presented in TABLE III as follows.

$\mathrm{T}_{\mathrm{ij}}=1(\mathrm{E}-17) \times\left(\mathrm{P}_{\mathrm{i}} \mathrm{P}_{\mathrm{i}}\right)^{0.930} \times\left(\mathrm{E}_{\mathrm{i}} \mathrm{E}_{\mathrm{j}}\right)^{0.995} \times \mathrm{D}_{\mathrm{ij}}{ }^{-0.999} \mathrm{x} \mathrm{Ta}_{\mathrm{ij}}{ }^{-1.000}$

TABLE III. ACCURACY CALCULATION For PREVIOUS Model

\begin{tabular}{|c|l|l|l|l|l|l|}
\hline SSE & Flight & $\begin{array}{c}\text { Tij } \\
\text { pax/month }\end{array}$ & $\begin{array}{c}\text { Tij' } \\
\text { pax/month }\end{array}$ & $|\mathbf{D}|$ & $\begin{array}{c}\text { D\% } \\
\%\end{array}$ & $\begin{array}{c}\text { MAE } \\
\%\end{array}$ \\
\hline \multirow{2}{*}{814.770} & $\begin{array}{l}\text { GYO- } \\
\text { BJT }\end{array}$ & 28.75 & 0.210 & 28.540 & 99.27 & \multirow{2}{*}{49.87} \\
\cline { 2 - 6 } & $\begin{array}{l}\text { GYO- } \\
\text { KNO }\end{array}$ & 29.50 & 29.360 & 0.140 & 0.47 & \\
\hline
\end{tabular}

3) Model 1 : Population and Distance: The Model 1 use the population for attraction mass and the distance as impedance. Each are powered differently. Model development produce this result. The powered are 1.001 for $\mathrm{P}_{\mathrm{i}}, 0.999$ for $\mathrm{P}_{\mathrm{j}}$, and -0.995 for $\mathrm{D}_{\mathrm{ij}}$. The coefficient $\mathrm{K}$ is of 2.3 E-8. This give a SSE of 680.554 and the error of $90.3 \%$ for GYO-BJT, and of $8.7 \%$ for GYO-KNO. The Model is presented in (8) below, while the accuracy calculation result is presented in TABLE IV as follows.

$T_{i j}=2.3(E-8) \times P_{i}^{1.001} \times P_{j}^{0.999} \times D_{i j}{ }^{-0.995}(8)$

TABLE IV. ACCURACy CALCULATION For MOdel 1

\begin{tabular}{|c|l|l|l|c|c|c|}
\hline SSE & Flight & $\begin{array}{c}\text { Tij } \\
\text { pax/month }\end{array}$ & $\begin{array}{c}\text { Tij' } \\
\text { pax/month }\end{array}$ & $|\mathbf{D}|$ & $\begin{array}{c}\text { D\% } \\
\%\end{array}$ & $\begin{array}{c}\text { MAE } \\
\%\end{array}$ \\
\hline \multirow{2}{*}{680.554} & $\begin{array}{l}\text { GYO- } \\
\text { BJT }\end{array}$ & 28.750 & 2.790 & 25.960 & 90.30 & \multirow{2}{*}{49.50} \\
\cline { 2 - 6 } & $\begin{array}{l}\text { GYO- } \\
\text { KNO }\end{array}$ & 29.500 & 32.070 & 2.570 & 8.71 & \\
\hline
\end{tabular}

4) Model 2 : Economics and Distance: The Model 2 use the economic values as attraction mass, but the same distances as impedance elements. This model has a coefficient value $\mathrm{K}$ equal to $1.00 \mathrm{E}-11$. The power values are of 0.997 for $E_{i}$, of 1.000 for $E_{j}$, and of -1.000 for $D_{i j}$. This model produced SSE value of 752.013, and error value of $95.3 \%$ for GYO-BJT, and $4.5 \%$ for GYO-KNO. The Model is presented in (9) below, while the accuracy calculation result is presented in TABLE V.

$T_{i j}=1.00(E-11) \times E_{i}^{0.997} \times E_{j}^{1.000} \times D_{i j}^{-1.000}(9)$

TABLE V. ACCURACY CALCULATION For Model 2

\begin{tabular}{|c|l|l|l|l|l|c|}
\hline SSE & Flight & $\begin{array}{c}\text { Tij } \\
\text { pax/month }\end{array}$ & $\begin{array}{c}\text { Tij' } \\
\text { pax/month }\end{array}$ & $|\mathbf{D}|$ & $\begin{array}{c}\text { D\% } \\
\%\end{array}$ & $\begin{array}{c}\text { MAE } \\
\%\end{array}$ \\
\hline \multirow{2}{*}{752.013} & $\begin{array}{l}\text { GYO- } \\
\text { BJT }\end{array}$ & 28.750 & 1.360 & 27.390 & 95.27 & \multirow{2}{*}{49.91} \\
\cline { 2 - 6 } & $\begin{array}{l}\text { GYO- } \\
\text { KNO }\end{array}$ & 29.500 & 30.840 & 1.340 & 4.54 & \\
\hline
\end{tabular}


5) Model 3 : Population and Ticket Tariff: Third combination of variables is applied to the Model 3, by using populations as attraction mass and ticket tariffs as impedance elements. The modeling produced a coefficient value $\mathrm{K}$ of $7.0 \mathrm{E}-5$, the powers values of 0.980 for $\mathrm{Pi}$, of 0.997 for $\mathrm{P}_{\mathrm{j}}$, and of -0.991 for $\mathrm{Ta}_{\mathrm{ij}}$. The model has a SSE value of 579.848 , and errors values of $82.7 \%$ for GYO-BJT flight, and $12.7 \%$ for GYO-KNO flight. The Model is presented in (10), while the accuracy calculation result is presented in TABLE VI.

$$
T_{i j}=7.00(E-5) \times P_{i}^{0.980} \times P_{j}^{0.997} \times T a_{i j}^{-0.991}(10)
$$

TABLE VI. ACCURACy CALCULATION FOR MOdEl 3

\begin{tabular}{|c|l|l|l|c|c|c|}
\hline SSE & Flight & $\begin{array}{c}\text { Tij } \\
\text { pax/month }\end{array}$ & $\begin{array}{c}\text { Tij’ } \\
\text { pax/month }\end{array}$ & $\mid$ D $\mid$ & $\begin{array}{c}\text { D\% } \\
\%\end{array}$ & $\begin{array}{c}\text { MAE } \\
\%\end{array}$ \\
\hline \multirow{2}{*}{579.848} & $\begin{array}{l}\text { GYO- } \\
\text { BJT }\end{array}$ & 28.750 & 4.970 & 23.780 & 82.71 & \multirow{2}{*}{47.73} \\
\cline { 2 - 6 } & $\begin{array}{l}\text { GYO- } \\
\text { KNO }\end{array}$ & 29.500 & 33.260 & 3.760 & 12.75 & \\
\hline
\end{tabular}

6) Model 4 : Economics and Tariff: The last combination of variables applied to the Model 4 is by using the economics values as attraction mass and the ticket tariffs as impedance elements. The Model 4 has a coefficient value $\mathrm{K}$ of $2.2 \mathrm{E}-8$, the powers values of 0.999 for $\mathrm{E}_{\mathrm{i}}$, of 0.999 for $\mathrm{E}_{\mathrm{j}}$, and of -0.991 for $\mathrm{Ta}_{\mathrm{ij}}$. The model has a SSE value of 698.930 , and errors values of $91.7 \%$ for GYO-BJT flight, and $6.4 \%$ for GYO-KNO flight. The Model is presented in (11) below, while the accuracy calculation result is presented in TABLE VII as follows.

$$
T_{i j}=2.20(E-8) \times E_{i}^{0.999} \times E_{j}^{0.999} \times T a_{i j}^{-0.999}(11)
$$

TABLE VII. ACCURACY CALCULATION FOR MODEL 4

\begin{tabular}{|c|l|l|l|c|c|c|}
\hline SSE & Flight & $\begin{array}{c}\text { Tij } \\
\text { pax/month }\end{array}$ & $\begin{array}{c}\text { Tij' } \\
\text { pax/month }\end{array}$ & $\mid$ D $\mid$ & $\begin{array}{c}\text { D\% } \\
\%\end{array}$ & $\begin{array}{c}\text { MAE } \\
\%\end{array}$ \\
\hline \multirow{2}{*}{698.930} & $\begin{array}{l}\text { GYO- } \\
\text { BJT }\end{array}$ & 28.750 & 2.380 & 26.370 & 91.72 & \multirow{2}{*}{49.05} \\
\cline { 2 - 6 } & $\begin{array}{l}\text { GYO- } \\
\text { KNO }\end{array}$ & 29.500 & 31.380 & 1.880 & 6.37 & \\
\hline
\end{tabular}

7) Comparaison of Different Variables Utilization: The first fact to be noted is that the best previous model is still worse compare to the all four new models. The best previous model gives Mean Absolute Error (MAE) of $49.88 \%$, while the best of the new four models produce MAE of $47.74 \%$. This fact indicates that utilising more complete possible variables does not always give a better model. The experiment case, among the four developed models, the Model 3 incorporating the population and ticket tariff give the best accuracy indicated by the least MAE and the least SSE. It can be noted also that less SSE produce less MAE. The accuracy comparaison are presented in TABLE VIII and Fig. 2 below.
TABLE VIII. ACCURACY COMPARAISON

\begin{tabular}{|l|l|l|l|l|l|}
\hline Model & Variables & SSE & $\begin{array}{c}\text { Error 1 } \\
\%\end{array}$ & $\begin{array}{c}\text { Error 2 } \\
\%\end{array}$ & $\begin{array}{c}\text { MAE } \\
\%\end{array}$ \\
\hline 0 & PE/DTa & 814.770 & $99.3 \%$ & $0.5 \%$ & $49.88 \%$ \\
\hline 1 & $\mathrm{P} / \mathrm{D}$ & 680.554 & $90.3 \%$ & $8.7 \%$ & $49.50 \%$ \\
\hline 2 & $\mathrm{E} / \mathrm{D}$ & 752.013 & $95.3 \%$ & $4.5 \%$ & $49.90 \%$ \\
\hline 3 & $\mathrm{P} / \mathrm{Ta}$ & 579.848 & $82.7 \%$ & $12.8 \%$ & $47.74 \%$ \\
\hline 4 & $\mathrm{E} / \mathrm{Ta}$ & 698.930 & $91.7 \%$ & $6.4 \%$ & $49.05 \%$ \\
\hline \multicolumn{6}{|l|}{ Note $: \mathrm{P}=$ population, $\mathrm{E}=$ economic, $\mathrm{D}=$ distance, Ta $=$ ticket tariff } \\
\hline
\end{tabular}

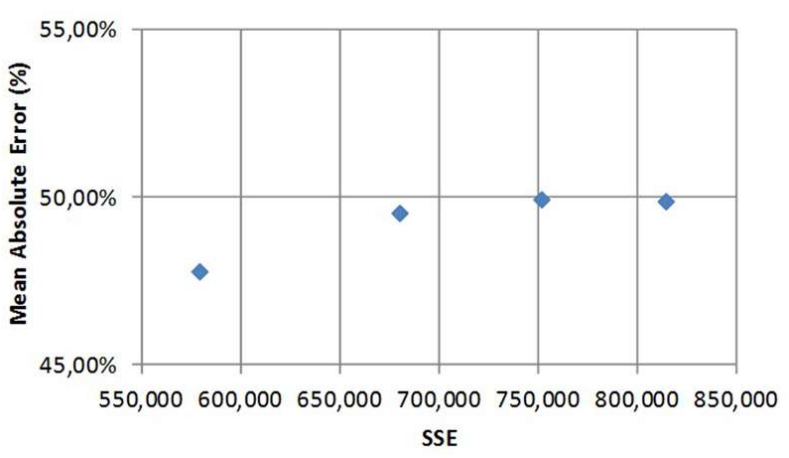

Fig. 2. Relation between the MAE and the SSE.

\section{CONCLUSIONS}

Several important points can be concluded from this research. Those remarks are presented as follows. Utilisation of different variables produce different model accuracy level. Utilisation of more complete variables does not always give better result. For this case, the best combination of variables is Population and Ticket Tariff. The best DGTDM developed is $\mathrm{Tij}=7.0 \mathrm{E}-5 \mathrm{Pi} 0.980 \mathrm{Pj} 0.997$ Taij-0.991. The powering values for all variables are all closed to 1 . Generally the four variables are appropriate to be used, inwhich better combination should be investigated for each case. It is better to use Mean Absolute Error for measuring overall accuracy.

The research strenghten the previous research conclusions that the Direct Gravity Trip Distribution Model can be used for cases inwhich calculation of Trip Generation, Modal Split, and Traffic Assignment is not an obligation, such for Air Transport and Sea Transport.

Further curiosity was induced, such as investigating of using different measure for minimization, developing the calculation method systematically, and investigating the usage of gravity model for different air and sea transportation demand cases.

\section{REFERENCES}

[1] O.Z. Tamin. Transportation Planning and Modeling. ITB Publisher. 2000 (in Indonesian)

[2] R.A.A. Soemitro \& H. Suprayitno. JMAIF 2 (Suplement 1) page : 113. 2018.

[3] H. Suprayitno \& R.A.A. Soemitro. JMAIF 2(1) page : 1-10. 2018.

[4] H. Suprayitno. ICCEE 2019 paper 265. 2019.

[5] M.M.M. Abdel-Aal, AEJ 53(3). 2014.

[6] H. Abdel-Latif (1999). Research Gate. Downloaded 18/08/2019. 
[7] G.D. Long, Research Report Number 60-13, Texas A\&M University. 1968.

[8] H. Suprayitno, IPTEK Journal of Engineering 4(3) 2018.

[9] H. Suprayitno, V. Ratnasari \& N. Saraswati, IOP Conference Series : Material Science and Engineering 267(1) 012209. 2017.

[10] H. Suprayitno, V. Ratnasari \& N. Saraswati, IPTEK The Journal of Engineering, 4(1) 2018.

[11] H. Suprayitno, V. Ratnasari, N. Saraswati \& C.P. Fajrinia, IPTEK The Journal for Technology and Science 29(1) 5-10 2018.

[12] H. Suprayitno, Prosiding Simposium FSTPT 2. 1999.

[13] BPS Blangkajeren, Blangkajeren Regency in 2018. 2019 (in Indonesian).

[14] BPS Banda Aceh, Banda Aceh City in 2018. 2019 (in Indonesian).

[15] BPS Medan, Medan City in 2018. 2019 (in Indonesian). 